\title{
FAKTOR PENYAKIT INFEKSI, PENGGUNAAN OBAT DAN GIZI IBU HAMIL TERHADAP TERJADINYA KELAINAN KONGENITAL PADA BAYI BARU LAHIR
}

\author{
Anita \\ Jurusan Keperawatan Poltekkes Tanjungkarang \\ Email: anitabustami@yahoo.co.id
}

\begin{abstract}
Infectious Disease Factors, Drug Use and Nutrition Of Pregnant Women on The Occurrence of Congenital Abnormalities in Newborns. The incidence of congenital abnormalities ranges was from 15 per 1000 births. This study was to know the infectious factor, medicine and nutrition of mother to congenital abnormalities in newborn in Perinatology room, Bandar Lampung Hospital, in 2016. This study was quantitative research, case control study, secondary data. The population were all infants treated in the Perinatology Room of Bandar Lampung Hospital, in 2016. Sample were 112 infants (56 as cases and 56 as controls), research variables were included infectious factors, drugs, nutrition and congenital anomalies. The result showed infection factor 27 (48\%), drug factor 24 (43\%), and nutrient factor less $25(45 \%)$. There were correlation of infectious factor $(\mathrm{p}$-value $=0,001)$, drug use factor ( $\mathrm{p}$-value $=0,001$ ), nutritional factor ( $p$-value $=0,000$ ) with congenital abnormalities in newborn. The most dominant factor was nutritional factor $(\mathrm{p}$-value $=0.000$ ) with $\mathrm{OR}=10,132$.
\end{abstract}

Keywords: Infection, Medicine, Nutrition, Congenital

\begin{abstract}
Abstrak: Faktor Penyakit Infeksi, Penggunaan Obat Dan Gizi Ibu Hamil terhadap Terjadinya Kelainan Kongenital pada Bayi Baru Lahir. Angka kejadian kelainan kongenital berkisar 15 per-1000 kelahiran. Tujuan penelitian ini untuk mengetahui factor infeksi, obat dan gizi ibu terhadap kelainan congenital pada bayi baru lahir di ruang Perinatologi RSAM Bandar Lampung tahun 2016. Jenis penelitian kuantitatif, desain studi kasus kontrol, data sekunder. Populasi adalah seluruh bayi yang dirawat di Ruang Perinatologi RSAM Bandar Lampung tahun 2016, sampel sejumlah 112 (56 kasus dan 56 kontrol), variabel penelitian meliputi faktor infeksi, obat,gizi dan kelainan kongenital.Hasil penelitian faktor infeksi 27 (48\%), faktor obat 24 (43\%), dan faktor gizi kurang sejumlah 25 (45\%). Ada hubungan faktor infeksi ( $p$-value $=0,001)$, faktor penggunaan obat $(p$-value $=0,001)$, faktor gizi $(p$-value $=0,000)$ dengan kelainan kongenital pada bayi baru lahir. Faktor paling dominan adalah faktor gizi $(p$-value $=0,000)$ dengan nilai $\mathrm{OR}=10,132$.
\end{abstract}

Kata kunci: Infeksi, Obat, Gizi, Kongenital

Data kesehatan anak secara global tahun 2012 menunjukkan bahwa kelainan kongenital merupakan $4 \%$ penyebab kematian anak, sedangkan peranannya dalam kematian perinatal adalah 22\% (Effendi, 2014). Di Indonesia, kematian bayi baru lahir (neonatal) masih menjadi permasalahan kesehatan. Angka kematian bayi di Indonesia adalah 32/1000 kelahiran hidup dan kematian neonatal 19/1000 kelahiran hidup (BKKBN., BPS., Kemenkes., Measure DHS., ICF Internasional, 2013). Saat ini, kelainan bawaan mempunyai kontribusi yang cukup besar sebagai penyebab kematian neonatal.

Data laporan BPPK, Depkes RI (2008) menyatakan bahwa sebesar $1,4 \%$ bayi baru lahir usia $0-6$ hari pertama kelahiran dan $18,1 \%$ bayi baru lahir usia 7-28 hari meninggal disebabkan karena kelainan bawaan. Data WHO SEARO tahun 2010 dalam Gustina E (2016) memperkirakan prevalensi kelainan bawaan di Indonesia adalah 593 per 1000 kelahiran hidup. Jika setiap tahun lahir 5 juta bayi di Indonesia, maka akan ada sekitar 295.000 kasus kelainan bawaan pertahun.

Gustina E, (2016) menyatakan selain menyebabkan kematian neonatal, kelainan bawaan juga merupakan penyebab bayi lahir mati dan abortus spontan. Jika bayi bertahan hidup, banyak diantaranya yang menjadi penyandang disabilitas dan mengidap penyakit kronis. Kementerian Kesehatan RI telah melakukan surveilans sentinel bersama 13 RS terpilih di 9 provinsi sejak September 2014. Terdapat 15 jenis kelainan bawaan yang disurveilans dengan kriteria antara lain kelainan bawaan yang dapat dicegah, mudah dideteksi dan dapat dikoreksi (preventable, detecteble dan correctable) dan merupakan masalah kesehatan masyarakat. Dari 
data tersebut, terdapat 231 bayi mengalami kelainan bawaan. Sebagian besar lahir dengan 1 jenis kelainan bawaan (87\%) dan ditemukan pula bayi lahir dengan $>1$ jenis kelainan bawaan (13\%). Kelainan bawaan yang paling banyak ditemukan adalah dari kelompok sistem muskulo skeletal (talipes equinovarus) 22,3\%, sistem saraf (anenchepali, spina bifida dan meningochele) $22 \%$, celah bibir dan langit-langit $18,5 \%$ dan omphalocele $12,5 \%$.

Walaupun penyebab utama kelainan kongenital adalah faktor genetik, infeksi dan faktor lingkungan, namun sebenarnya banyak dari kelainan tersebut dapat dicegah, misalnya melalui vaksinasi dan konsumsi zat tertentu, seperti asam folat dan iodium, menghindari mengkonsumsi obat yang tidak direkomendasikan oleh dokter, alkohol atau zat berbahaya seperti pengawet dan pewarna buatan, hindari terpapar dari bahan berbahaya dan beracun seperti timbal, merkuri dan pestisida, beraktivitas fisik/ olahraga yang teratur, dan menghindari asap rokok selama kehamilan.

Menurut Sofian (2012) diperkirakan frekuensi malformasi kongenital akan menjadi 45\% untuk bayi-bayi yang dapat hidup sampai usia satu tahun. Manuaba (2012) menyatakan kejadian kelainan kongenital sekitar $0,2 \%$ sampai $0,4 \%$ dari seluruh persalinan. Pada setiap rumah sakit kejadiannya bervariasi tergantung dari berbagai sebab. Selanjutnya Effendi (2014) menyatakan kelainan bayi dengan kelainan bawaan ini menimbulkan berbagai permasalahan dalam keluarga meliputi perasaan tertekan, malu, rasa bersalah, serta masalah perhatian dan pembiayaan yang lebih besar dari anak normal.

Angka kejadian kelainan kongenital secara keseluruhan di Provinsi Lampung tidak ditemukan catatan secara pasti, namun Data rekam medik RSUD Dr.H.Abdul Moeloek (RSAM) Provinsi Lampung Tahun 2015 jumlah bayi baru lahir dengan kelainan kongenital berjumlah $183(17,24 \%)$ dari 1.061 angka kelahiran bayi. RSAM adalah rumah sakit rujukan tertinggi di Provinsi Lampung, dengan fasilitas diagnostik kelainan kongenital yang memadai dan kamar operasi lengkap, sehingga angka kejadian menjadi lebih tinggi dibandingkan rumah sakit lain yang ada di Provinsi Lampung.

Perlu dilakukan pemeriksaan yang lebih baik untuk penapisan kemungkinan adanya kelainan kongenital sedini mungkin, terutama pada ibu-ibu hamil dengan risiko tinggi melahirkan bayi dengan kelainan kongenital. Penelitian lanjut untuk mengetahui lebih baik faktor-faktor yang dapat mempengaruhi kejadian kelainan kongenital. Penelitian faktor penyakit infeksi, penggunaan obat dan gizi ibu hamil merupakan faktor yang dapat dicegah, untuk itu penelitian tentang faktor tersebut menjadi penting bagi tenaga kesehatan.

\section{METODE PENELITIAN}

Jenis penelitian kuantitatif dan rancangan penelitian case control. Populasi kasus yaitu seluruh bayi yang mengalami kelainan kongenital sejumlah 204 kasus, dan populasi kontrol yaitu seluruh bayi lahir normal di ruang Perinatologi dan Delima RSAM Bandar Lampung tahun 2016 sejumlah 1.200 orang. Sampel penelitian tiap kelompok adalah 56 sampel kasus dan 56 sampel kontrol, sehingga total sampel sebanyak 112 responden. Teknik pengambilan sampel dengan sistematik random sampling. Uji statistik menggunakan uji chi square dan regresi logistic.

\section{HASIL}

Tabel 1. Distribusi Frekuensi Karakteristik Responden\&Variabel Penelitian

\begin{tabular}{llrrrr}
\hline \multirow{2}{*}{ Karakteristik responden } & \multicolumn{3}{c}{ Kasus } & \multicolumn{3}{c}{ Kontrol } \\
\cline { 3 - 6 } & & n & \% & \multicolumn{1}{c}{ n } & \% \\
\hline Pendidikan & SD-SMP & 42 & 75 & 49 & 88 \\
& SMA-PT & 14 & 25 & 7 & 14 \\
\hline Pekerjaan & Ibu RT & 51 & 91 & 47 & 83 \\
& Bekerja & 5 & 9 & 9 & 17 \\
\hline Infeksi & Infeksi & 27 & 48 & 10 & 18 \\
& Tidak infeksi & 29 & 52 & 46 & 82 \\
\hline Terpapar & Terpapar & 24 & 43 & 7 & 12,5 \\
Obat & Tidak & 32 & 57 & 49 & 87,5 \\
& Terpapar & & & & \\
\hline Status Gizi & Gizi kurang & 25 & 45 & 5 & 9 \\
& Gizi baik & 31 & 55 & 51 & 91 \\
\hline
\end{tabular}

Pada Tabel1 diketahui Karakteristik responden berpendidikan SD-SMP pada kelompok kasus sejumlah $75 \%$ dan kelompok kontrol 88\%. Pekerjaan terbanyak ibu rumah tangga, pada kelompok kasus sejumlah $91 \%$ dan kelompok kontrol 83\%.Distribusi frekuensi responden pada kelompok kasus dengan faktor infeksi saat hamil sejumlah 27 (48\%) dan pada kelompok kontrol sejumlah $10(18 \%)$. Faktor terpapar obat sejumlah 24(43\%) dan pada kelompok kontrol sejumlah $7(12,5 \%)$. Faktor status gizi kurang sejumlah 25(45\%) dan pada kelompok kontrol sejumlah 5 (9\%). 
Tabel 2. Hubungan Faktor Infeksi dengan Kelainan Kongenital pada Bayi Baru Lahir

\begin{tabular}{lcccc}
\hline \multirow{2}{*}{ FaktorInfeksi } & \multicolumn{4}{c}{ Ibu bersalin } \\
\cline { 2 - 5 } & \multicolumn{3}{c}{ Kasus } & Kontrol \\
\cline { 2 - 5 } & $\mathbf{n}$ & $\boldsymbol{\%}$ & $\mathbf{n}$ & $\boldsymbol{\%}$ \\
\hline Infeksi saat hamil & 27 & 48 & 10 & 18 \\
\hline Tdk infeksi saat hamil & 29 & 52 & 46 & 82 \\
\hline Total & 56 & 100 & 56 & 100 \\
\hline OR=4,283 (1,808-10,137); $p$-value $=0,001$ \\
\hline
\end{tabular}

Berdasarkan tabel 2 diketahui bahwa dari 112 responden pada kelompok kasus yang memiliki faktor infeksi sebesar $23(41 \%)$, pada kelompok kontrol $10(18 \%)$. Hasil uji statistik diperoleh $p$-value $0,001<\alpha(0,05)$, sehingga Ho ditolak, menunjukkan bahwa ada hubungan faktor infeksi dengan kelainan kongenital pada bayi baru lahir. Nilai OR 4,283 yang berarti ibu memiliki faktor infeksi berisiko melahirkan bayi dengan kelainan kongenital sebesar 4,283 kali dibandingkan ibu yang tidak memiliki faktor infeksi.

Tabel 3. Hubungan Faktor Obat dengan Kelainan Kongenital pada Bayi Baru Lahir

\begin{tabular}{llrrr}
\hline \multirow{2}{*}{ FaktorObat } & \multicolumn{4}{c}{ Ibubersalin } \\
\cline { 2 - 5 } & \multicolumn{3}{c}{ Kasus } & Kontrol \\
\cline { 2 - 5 } & $\mathbf{n}$ & $\boldsymbol{\%}$ & $\mathbf{n}$ & $\boldsymbol{\%}$ \\
\hline Terpapar obat & 24 & 43 & 7 & 12,5 \\
\hline Tidak terpapar obat & 32 & 57 & 49 & 49 \\
\hline Total & 56 & 100 & 56 & 100 \\
\hline OR $=5,250(2,025-13,609) ;$ & $p$-value $=0,001$ \\
\hline
\end{tabular}

Berdasarkan tabel 3 diperoleh 112 responden pada kelompok kasus yang terpapar obat sebesar 24 (43\%), pada kelompok kontrol sebesar $7(12,5 \%)$. Hasil uji statistik diperoleh $p$ value $0,001<\alpha(0,05)$, sehingga Ho ditolak. Hal ini menunjukkan bahwa ada hubungan faktor obat dengan kelainan kongenital pada bayi baru lahir. Nilai OR 5,250 yang berarti ibu yang terpapar obat selama hamil (faktor obat) berisiko melahirkan bayi dengan kelainan kongenital sebesar 5,250 kali dibandingkan ibu yang tidak terpapar obat.

Tabel 4. Hubungan Faktor Gizi dengan Kelainan Kongenital pada Bayi Baru Lahir

\begin{tabular}{lcccc}
\hline \multirow{2}{*}{ Faktorgizi } & \multicolumn{4}{c}{ Ibu Bersalin } \\
\cline { 2 - 5 } & \multicolumn{2}{c}{ Kasus } & \multicolumn{3}{c}{ Kontrol } \\
\cline { 2 - 5 } & $\mathbf{n}$ & $\mathbf{\%}$ & $\mathbf{n}$ & $\boldsymbol{\%}$ \\
\hline Status gizi ibu kurang & 25 & 45 & 5 & 9 \\
\hline Status gizi ibu baik genetik & 31 & 55 & 51 & 91 \\
\hline Total & 56 & 100 & 56 & 100 \\
\hline OR=8,226 $(2,853-23,716) ;$ & $p$-value $=0,000$ \\
\hline
\end{tabular}

Berdasarkan tabel 4, dari 112 responden pada kelompok kasusdengan status gizi kurang sebesar 25 (45\%), pada kelompok kontrol sebesar 5 (9\%). Hasil uji statistik diperoleh $p$-value $0,004<\alpha(0,05)$, sehingga Ho ditolak. Hal ini menunjukkan bahwa ada hubungan faktor gizi dengan kelainan kongenital pada bayi baru lahir. Nilai OR yang diperoleh yaitu 8,226 yang berarti ibu dengan status gizi kurang berisiko melahirkan bayi dengan kelainan kongenital sebesar 8,226 kali dibandingkan ibu yang berstatus gizi baik.

\section{Tabe1 5. Model Multivariat Regresi Logistik}

\begin{tabular}{|c|c|c|c|c|}
\hline \multirow[t]{2}{*}{ Variabel } & \multirow{2}{*}{$\begin{array}{c}p- \\
\text { value }\end{array}$} & \multirow[t]{2}{*}{ OR } & \multicolumn{2}{|c|}{$\begin{array}{l}95 \% \text { CI for EXP } \\
\text { (B) }\end{array}$} \\
\hline & & & Lower & Upper \\
\hline Faktor infeksi & 0,000 & 0,127 & 0,044 & 0,363 \\
\hline Faktor obat & 0.001 & 6,858 & 2,193 & 21,445 \\
\hline Faktor gizi & 0,000 & 10,132 & 3,024 & 33,946 \\
\hline
\end{tabular}

Dari kedua variabel tersebut faktor gizi mempunyai nilai $p$-valuelebih kecil dan OR terbesar sehingga faktor gizi merupakan faktor dominan dari faktor yang berhubungan dengan infeksi dan obat pada kelainan kongenital pada BBL.

\section{PEMBAHASAN}

Hasil penelitian menunjukkan bahwa distribusi frekuensi responden pada kelompok kasus dengan menderita infeksi saat hamil sejumlah 27(48\%) dan pada kelompok kontrol sejumlah 10 responden (18\%). Menurut Sofian (2012) infeksi terutama diderita ibu dalam proses organogenesis (triwulan pertama kehamilan) dapat menimbulkan kelainan kongenital. Infeksi rubella yang dapat menyebabkan kelainan jantung, mata, dan susunan syaraf pusat janin. Infeksi virus lain juga dapat menimbulkan kelainan bawaan. Seperti virus sitomegalovirus dapat mengakibatkan hidrosefalus, mikrosefalus dan mikroftalmia (Sofian, 2012).

Adanya infeksi tertentu dalam periode organogenesis ini dapat menimbulkan gangguan dalam pertumbuhan suatu organ tubuh. Infeksi pada trimester pertama di samping dapat menimbulkan kelainan kongenital dapat pula meningkatkan kemungkinan terjadinya abortus. Sebagai contoh infeksi virus pada trimester pertama ialah infeksi oleh virus Rubella. Bayi yang dilahirkan oleh ibu yang menderita infeksi Rubella pada trimester pertama dapat menderita kelainan kongenital pada mata sebagai katarak, tuli dan kelainan jantung bawaan (Manuaba, 2012). 
Hasil penelitian ini mendukung hasil penelitian Darussalam tentang penyakit yang diderita ibu dengan kelainan congenital pada bayi yang dilahirkan. Hasil penelitian ini juga sesuai dengan data dinas kesehatan provinsi Lampung yang menjelaskan faktori infeksi sejumlah 44 kasua dari 164.062 yaitu 2,7\% (Dinkes Provinsi Lampung, 2012).

Hasil Penelitian diperoleh distribusi frekuensi responden pada kelompok kasus yang terpapar obat sejumlah 24 responden $(32 \%)$ dan pada kelompok kontrol sejumlah 7 responden $(12,5 \%)$. Beberapa jenis obat tertentu dan jamuajamuan yang diminum wanita hamil pada trimester pertama kehamilan diduga sangat erat hubungannya dengan terjadinya kelainan kongenital pada bayinya. Salah satu jenis obat yang telah diketahui dagat menimbulkan kelainan kongenital ialah thalidomide yang dapat mengakibatkan terjadinya fokomelia atau mikromelia (Sofian, 2012). Angka kejadian karena faktor obat belum ada angka pastinya atau penelitian tentang jenis obat dan jamu-jamuan.

Hasil penelitian menyatakan bahwa distribusi frekuensi responden pada kelompok kasus ibu dengan status gizi kurang sejumlah 17 responden $(30 \%)$ dan pada kelompok kontrol sejumlah 4 responden (7\%). Ibu dengan kekurangan gizi dapat meningkatkan kemungkinan kelainan organ terutama saat pembentukan organ tubuh (Manuaba, 2012). Kekurangan beberapa zat penting selama hamil dapat menimbulkan kelainan pada janin. Frekuensi kelainan kongenital lebih tinggi pada ibu-ibu dengan gizi yang kurang selama kehamilan (Sofian, 2012).

Angka kejadian kelainan kongenital di Rumah Sakit Abdul Moeloek tahun 2010 karena kasus janin berat bayi lahir rendah sebanyak 27, $36 \%$, termasuk asfiksia akibat berat bayi rendah, Pembentukan organ tubuh janin memerlukan Ibu dengan kekurangan gizi dapat meningkatkan kemungkinan kelainan organ terutama saat pembentukan organ tubuh (Manuaba, 2012). Kekurangan beberapa zat penting selama hamil dapat menimbulkan kelainan pada janin. Frekuensi kelainan kongenital lebih tinggi pada ibu-ibu dengan gizi yang kurang selama kehamilan (Sofian, 2012).

\section{Faktor Infeksi dengan Kelainan Kongenital pada Bayi Baru Lahir}

Hasil penelitian menunjukkan bahwa dari 112 responden, ditemukan pada kelompok kasus dengan faktor infeksi sebesar 27 responden (48\%), pada kelompok kontrol sebesar 10 responden (18\%). P-value 0,001 menunjukkan bahwa ada hubungan faktor infeksi dengan kelainan kongenital pada bayi baru lahir di ruang Perinatologi RSAM Bandar Lampung 2016. Nilai OR 4,283 yang member arti bahwa ibu yang memiliki faktor infeksi berisiko melahirkan bayi dengan kelainan kongenital sebesar 4 kali dibandingkan ibu yang tidak memiliki faktor infeksi.

Infeksi terutama diderita ibu dalam proses organogenesis (triwulan pertama kehamilan) dapat menimbulkan kelainan kongenital. Infeksi rubella yang dapat menyebabkan kelainan jantung, mata, dan susunan syaraf pusat janin. Infeksi virus lain juga dapat menimbulkan kelainan bawaan. Seperti virus sitomegalovirus dapat mengakibatkan hidrosefalus, mikrosefalus dan mikroftalmia (Sofian, 2012). Adanya infeksi tertentu dalam periode organogenesis ini dapat menimbulkan gangguan dalam pertumbuhan suatu organ tubuh. Infeksi pada trimester pertama di samping dapat menimbulkan kelainan kongenital dapat pula meningkatkan kemungkinan terjadinya abortus. Sebagai contoh infeksi virus pada trimester pertama ialah infeksi oleh virus Rubella. Bayi yang dilahirkan oleh ibu yang menderita infeksi Rubella pada trimester pertama dapat menderita kelainan kongenital pada mata sebagai katarak, tuli dan kelainan jantung bawaan (Manuaba, 2012).

Beberapa infeksi lain pada trimester pertama yang dapat menimbulkan kelainan kongenital antara lain ialah infeksi virus sitomegalovirus, infeksi toksoplasmosis, kelainan-kelainan kongenital yang mungkin dijumpai ialah adanya gangguan pertumbuhan pada system saraf pusat seperti hidrosefalus, mikrosefalus, atau mikroftalmia. Infeksi pada ibu hamil juga bisa merupakan teratogen.

Berikut lebih rinci beberapa infeksi selama kehamilan yang dapat menyebabkan sejumlah kelainan bawaan:

1. Sindroma rubella kongenital ditandai dengan gangguan penglihatan atau pendengaran, kelainan jantung, keterbelakangan mental dan cerebral palsy.

2. Infeksi toksoplasmosis pada ibu hamil bisa menyebabkan infeksi mata yang bisa berakibat fatal, gangguan pendengaran, ketidakmampuan belajar, pembesaran hati atau limpa, keterbelakangan mental dan cerebral palsy.

3. Infeksi virus herpes genitalis pada ibu hamil, jika ditularkan kepada bayinya sebelum atau selama proses persalinan berlangsung, bisa menyebabkan kerusakan otak, cerebral palsy, gangguan penglihatan atau pendengaran serta kematian bayi. 
4. Penyakit ke-5 bisa menyebabkan sejenis anemia yang berbahaya, gagal jantung dan kematian janin.

5. Sindroma varicella kongenital disebabkan oleh cacar air dan bisa menyebabkan terbentuknya jaringan parut pada otot dan tulang, kelainan bentuk dan kelumpuhan pada anggota gerak, kepala yang berukuran lebih kecil dari normal, kebutaan, kejang dan keterbelakangan mental.

\section{Faktor Obat dengan Kelainan Kongenital pada Bayi Baru Lahir}

Hasil penelitian menjelaskan bahwa dari 112 responden pada kelompok kasus yang terpapar obat tanpa resep dokter saat hamil sebesar 24 responden (43\%), pada kelompok kontrol sebesar 7 responden (12,5\%). Hasil uji statistik diperoleh $p$-value 0,001 yang berarti $<\alpha$ $(0,05)$, sehingga Ho ditolak. Hal ini menunjukkan bahwa ada hubungan faktor obat dengan kelainan kongenital pada bayi baru lahir di ruang Perinatologi RSAM Bandar Lampung 2016. Nilai OR yang diperoleh yaitu 5,250 yang berarti ibu yang terpapar obat selama hamil (faktor obat) berisiko melahirkan bayi dengan kelainan kongenital sebesar 5 kali dibandingkan ibu yang tidak terpapar obat.

Beberapa jenis obat tertentu yang diminum wanita hamil pada trimester pertama kehamilan diduga sangat erat hubungannya dengan terjadinya kelainan kongenital pada bayinya. Salah satu jenis obat yang telah diketahui dagat menimbulkan kelainan kongenital ialah thalidomide yang dapat mengakibatkan terjadinya fokomelia atau mikromelia (Sofian, 2012).

Beberapa jenis jamu-jamuan yang diminum wanita hamil muda dengan tujuan yang kurang baik diduga erat pula hubungannya dengan terjadinya kelainan kongenital, walaupun hal ini secara laboratorik belum banyak diketahui secara pasti. Sebaiknya selama kehamilan, khususnya trimester pertama, dihindari pemakaian obat-obatan yang tidak perlu sama sekali; walaupun hal ini kadang-kadang sukar dihindari karena calon ibu memang terpaksa harus minum obat. Hal ini misalnya pada pemakaian trankuilaiser untuk penyakit tertentu, pemakaian sitostatik atau prepaat hormon yang tidak dapat dihindarkan; keadaan ini perlu dipertimbangkan sebaik-baiknya sebelum kehamilan dan akibatnya terhadap bayi.

Hasil penelitian mendukung teori Effendi 2014 yang menyatakan kelainan oleh faktor nongenetik adalah kelainan yang disebabkan oleh obat-obatan, teratogen, dan radiasi. Teratogen adalah obat, zat kimia, infeksi, penyakit ibu yang berpengaruh pada janin sehingga menyebabkan kelainan bentuk atau fungsi pada bayi yang dilahirkan. Beberapa teratogen yang diketahui dapat menyebabkan kelainan kongenital. Obatobatan seperti aspirin, parasetamol, sefalosporin dan aminoglikosida dinyatakan tidak teratogen, keamanannya pada kehamilan belum diketahui dan bila mungkin sebaiknya dihindari.

\section{Faktor Gizi dengan Kelainan Kongenital pada Bayi Baru Lahir \\ Hasil penelitian menunjukkan bahwa dari} 112 responden pada kelompok kasus sebesar 25 responden (45\%), pada kelompok kontrol sebesar 5 responden (9\%) dengan status gizi kurang. Hasil uji statistik diperoleh $p$-value 0,000 yang berarti $<\alpha(0,05)$, sehingga Ho ditolak. Hal ini menunjukkan bahwa ada hubungan faktor gizi dengan kelainan kongenital pada bayi baru lahir di ruang Perinatologi RSAM Bandar Lampung 2016. Nilai OR yang diperoleh yaitu 8,226 yang berarti ibu dengan status gizi kurang berisiko melahirkan bayi dengan kelainan kongenital sebesar 8 kali dibandingkan ibu yang berstatus gizi baik.

Ibu dengan kekurangan gizi dapat meningkatkan kemungkinan kelainan organ terutama saat pembentukan organ tubuh (Manuaba, 2012). Kekurangan beberapa zat penting selama hamil dapat menimbulkan kelainan pada janin. Frekuensi kelainan kongenital lebih tinggi pada ibu-ibu dengan gizi yang kurang selama kehamilan (Sofian, 2012). Pada binatang percobaan, kekurangan gizi berat dalam masa kehamilan dapat menimbulkan kelainan kongenital. Pada manusia, menunjukkan bahwa frekuensi kelainan kongenital pada bayibayi yang dilahirkan oleh ibu yang kekurangan makanan lebih tinggi bila dibandingkan dengan bayi-bayi yang lahir dari ibu yang baik gizinya. Pada binatang percobaan, adanya defisiensi protein, vitamin A ribofIavin, folic acid, thiamin dan lain-Iain dapat menaikkan kejadian \& kelainan kongenital.

Menjaga kesehatan janin tidak hanya dilakukan dengan menghindari teratogen, tetapi juga dengan mengkonsumsi gizi yang baik. Salah satu zat yang penting untuk pertumbuhan janin adalah asam folat. Kekurangan asam folat bisa meningkatkan resiko terjadinya spina bifida atau kelainan tabung saraflainnya. Karena spina bifida bisa terjadi sebelum seorang wanita menyadari bahwa dia hamil, maka setiap wanita usia subur sebaiknya mengkonsumsi asam folat minimal sebanyak 400 mikrogram/hari. 
Hasil analisis menunjukkan bahwa faktor yang paling dominan yang berhubungan dengan kelainan kongenital di Ruang perinatologi Rumah Sakit Abdul Moeloek Bandar Lampung ahun 2014 adalah faktor gizi dengan nilai $p$-value 0,000, dengan nilai OR 10,132.Kelainan kongenital banyak yang tidak diketahui penyebabnya. Faktor janinnya sendiri dan faktor lingkungan hidup janin diduga dapat menjadi faktor penyebabnya. Masalah sosial, hipoksia, hipotermia, atau hipertermia dan faktor sosial lainnya dapat mempengaruhi terjadinya kelainan kongenital (Sofian, 2012). Seringkali penyebab kelainan kongenital tidak diketahui. Faktor lingkungan atau non genetik yang terpengaruh terhadap pertumbuhan dan perkembangan janin adalah unsur gizi yang dikonsumsi ibu, jika ibu mengalami kekurangan gizi maka pembentukan tubuh janin juga akan kurang sempurna.

Hasil analisis multivariat sejalan dengan teori (Manuaba, 2012) yaitu ibu dengan kekurangan gizi dapat meningkatkan kemungkinan kelainan organ terutama saat pembentukan organ tubuh. Kekurangan beberapa zat penting selama hamil dapat menimbulkan kelainan pada janin. Frekuensi kelainan kongenital lebih tinggi pada ibu-ibu dengan gizi yang kurang selama kehamilan (Sofian, 2012). Pada binatang percobaan, kekurangan gizi berat dalam masa kehamilan dapat menimbulkan kelainan kongenital. Pada manusia, menunjukkan bahwa frekuensi kelainan kongenital pada bayibayi yang dilahirkan oleh ibu yang kekurangan makanan lebih tinggi bila dibandingkan dengan bayi-bayi yang lahir dari ibu yang baik gizinya. Pada binatang percobaan, adanya defisiensi protein, vitamin A ribofIavin, folic acid, thiamin dan lain-Iain dapat menaikkan kejadian \& kelainan kongenital.

Hasil analisis yang menyatakan faktor gizi merupakan faktor dominan, sesuai dengan teori tentang tumbuh kembang janin, jika ibu mengalami kekurangan gizi maka anak akan mengalami hambatan dalam pmbntukan organ, pertumbuhan maupun perkembangan, sehingga dapat terjadi kelainan congenital seperti tidak lengkapnya organ tubuh atau gangguan fungsi tubuh tersebut.

\section{SIMPULAN}

Kesimpulan dari faktor infeksi, obat dan gizi terhadap kelainan kongenital pada bayi baru lahir disajikan sebagai berikut:
1. Distribusi frekuensi responden pada kelompok kasus yang mempunyai faktor infeksi 27 (48\%), faktor obat 24 (43\%), dan faktor gizi kurang sejumlah 25 responden (45\%). Sedangkan pada kelompok kontrol variabel tersebut distribusinya lebih kecil.

2. Ada hubungan antara faktor infeksi dengan kelainan kongenital pada bayi baru lahir, nilai $p$-value $=0,001$.

3. Ada hubungan antara faktor obat dengan kelainan kongenital pada bayi baru lahir, nilai $p$-value $=0,001$.

4. Ada hubungan antara faktor gizi dengan kelainan kongenital pada bayi baru lahir, nilai $p$-value $=0,000$

5. Faktor yang paling dominan yang berhubungan dengan kelainan congenital pada bayi baru lahir adalah faktor gizi $(p$ value $=0,000$ ) dengan nilai $\mathrm{OR}=10,132$

\section{SARAN}

Berdasarkan kesimpulan di atas, maka saran dari penelitian ini adalah:

1. Tenaga kesehatan yang bekerja di poliklinik KIA, ruang rawat perinatologi dan kebidanan, untuk meningkatkan promosi kesehatan tentang faktor penyebab kelainan kongenital pada janin terutama faktor infeksi, penggunaan obat tanpa resep dokter dan gizi selama hamil, sehingga pencegahan dini dapat dilakukan. Pendidikan kesehatan dapat dilakukan dengan konseling calon pengantin maupun kelas ibu, terutama ibu usia produktif.

2. Kerjasama antar berbagai profesi dalam upaya mengatasi masalah gizi, deteksi faktor penyebab dan kelainan kongenital janin perlu ditingkatkan, melalui kegiatan pro aktif dengan menggunakan media elektronik untuk mengingatkan waktu kontrol ataupun konsultasi, serta kunjungan rumah.

3. Rekomendasi penelitian dengan produk teknologi tepat guna, yang dapat dilakukan dalam mendeteksi adanya kelainan kongenital, sehingga kemandirian ibu dan masyarakat dalam mengenal masalah kesehatan dapat ditingkatkan.

4. Masalah gizi selalu menjadi masalah utama, upaya lintas sektoral perlu dilakukan kementerian kesehatan, baik dalam bidang sosial ekonomi, pendidikan, dan kesehatan, sehingga setiap wanita produktif tidak mengalami masalah kesehatan terutama gizi kurang atau buruk. 


\section{DAFTAR PUSTAKA}

BKKBN., BPS., Kemenkes., Measure DHS., ICF Internasional. 2013. Survei Demografi \& Kesehatan Indonesia. http://chnrl.org/pelatihan-demografi/SDKI2012.pdf

BPPK., Depkes RI. 2008. Riset Kesehatan Dasar 2007. https://www.k4health.org/sites/default/files /laporanNasional\%20Riskesdas\%202007.p df

Dinkes Provinsi Lampung. 2012. Profil Dinas Kesehatan Provinsi Lampung. Lampung: Dinkes Provinsi Lampung.

Effendi, S.H. 2014. Penanganan Bayi dengan Kelainan Kongenital dan Konseling
Genetik, Bandung, Dies Natalis Unpad, 2021 September 2014.

Gustina, E. 2016. 3 Maret: Hari Kelainan Bawaan Sedunia Cegah Bayi Lahir Cacat dengan Pola Hidup Sehat, www.depkes.go.id/.../3-maret-harikelainan-bawaan-sedunia-cegah-bayi-lahircacat-d (Diakses tgl 20 Desember 2016).

Manuaba, Ida Bagus Gde. 2012. Ilmu Kebidanan, Penyakit Kandungan, dan KB untuk Pendidikan Bidan, Edisi 2. Jakarta: EGC.

RSAM. 2014. Laporan Bulanan Perinatologi. RSAM. Lampung.

Sofian, Amru. 2012. Sinapsis Obsetric Rustam Muckhtar. Jakarta: EGC. 